\begin{tabular}{lccc} 
VERSITA & GOSPODARKA & SUROWCAMI & MINERALNYMI \\
\hline Tom 29 & 2013 & Zeszyt 4 \\
& & DOI 10.2478/gospo-2013-0044 &
\end{tabular}

\title{
Petrographic-mineralogical and textural changes in reservoir and sealing rocks (Zaosie anticline) as a result of a long-term experiment in $\mathrm{CO}_{2}$-brine-rock interactions
}

\section{Introduction}

Due to the industrialization as well as socioeconomic development of human society, the consumption of fossil fuels has greatly increased. Air pollution and the greenhouse effect associated with the emission of carbon dioxide have become a major threat to the environment on a global scale. Regardless of the recognition of this problem, $\mathrm{CO}_{2}$ emissions have continued to increase in recent decades (Shukla et al. 2010; Wang et al. 2013).

The geological storage of carbon dioxide in deep saline aquifers is considered to be one of key options for reducing anthropogenic $\mathrm{CO}_{2}$ emissions and stabilizing atmospheric $\mathrm{CO}_{2}$ levels, in order to mitigate global warming without drastically changing energy-producing technologies (Gunter et al. 1993; Bachu et al. 1994; Fischer et al. 2013). The effects of injected $\mathrm{CO}_{2}$ on rocks and reservoir fluids refer to many aspects, such as the kinetics of $\mathrm{CO}_{2}$ dissolution in reservoir fluids, the kinetics of mineral trapping, the appearance of new mineral phases, the migration of gas within the reservoir, the geological storage capacity, the sealing properties of cap rocks, and many others. Therefore, it is necessary to determine the extent of $\mathrm{CO}_{2}$-water-rock interaction during preliminary studies of the usefulness of selected formations and geological structures for underground storage (Tarkowski, Wdowin

* Ph.D., ** D.Sc. Eng., Mineral and Energy Economy Research Institute of the Polish Academy of Sciences, Kraków, Poland; e-mail: wdowin@min-pan.krakow.pl; tarkowski@min-pan.krakow.pl

*** D.Sc. Eng., AGH University of Science and Technologies, Kraków, Poland; e-mail: gpmmanec@cyf-kr.edu.pl 
2011). The study of these processes is essential, and permits planning the details of safe underground $\mathrm{CO}_{2}$ storage operations as well optimizing the process of $\mathrm{CO}_{2}$ injection (Tarkowski, Wdowin 2011; Zarębska et al. 2012; Wdowin et al. 2013; Baran et al. 2013).

The objective of this work was evaluation of alterations resulting from the interaction between $\mathrm{CO}_{2}$-saturated brine and selected sandstones, claystones, and mudstones in a long-term experiment.

\section{Materials and Methods}

\subsection{Materials}

The research material consisted of reservoir and sealing rock samples from the Zaosie anticline, located at the southwestern end of the Rawa structural unit of the Kujawian Swell (Marek et al. 2011).

Four drill core rock samples were chosen from the Zaosie anticline (from Buków 2 and Zaosie 2 boreholes); two samples from reservoir rocks and two samples from sealing rocks (Table 1). Similar samples were studied within the framework of the project Assessment of formations and structures for safe $\mathrm{CO}_{2}$ geological storage, including monitoring plans, and the results were presented in several publications (Wdowin, Tarkowski 2010; Tarkowski et al. 2010; Labus et al. 2010). Mineralogical analyses prior to the experiment in this study were repeated to verify the reproducibility of the results.

TABLE 1

List of samples selected for study

TABELA 1

Spis próbek wytypowanych do badań

\begin{tabular}{|c|c|c|c||}
\hline \hline No. & Borehole & Depth [m] & Sample lithology \\
\hline \hline 1. & Zaosie 2 & 838.10 & sandstone \\
\hline 2. & Zaosie 2 & 912.40 & claystone \\
\hline 3. & Buków 2 & 1435.50 & sandstone \\
\hline 4. & Buków 2 & 1436.00 & mudstone \\
\hline
\end{tabular}

\subsection{Experiment}

The experiment was conducted in four, custom-built, stainless steel autoclaves $\left(1.8 \mathrm{dm}^{3}\right.$ each) designed for the purposes of this study. The samples of rocks were placed on Petri dishes in glass cylinders filled with brine and inserted into the autoclaves. Experiments with 
samples of reservoir sandstones and sealing claystones or mudstones, from both Zaosie 2 and Buków 2 boreholes, were run in separate autoclaves. The solution was not in direct contact with the walls of the autoclave. The brine solution was prepared to model the composition of waters in a saline aquifer from the Jurassic formations of the Zaosie anticline area. The solution contained the following: $741 \mathrm{mg} / 1 \mathrm{Cl}^{-}, 396 \mathrm{mg} / 1 \mathrm{SO}_{4}{ }^{2-}, 195 \mathrm{mg} / 1 \mathrm{HCO}_{3}{ }^{-}$, $334 \mathrm{mg} / \mathrm{l} \mathrm{CO}_{3}{ }^{2-}, 1.2 \mathrm{mg} / \mathrm{l} \mathrm{Ca}^{2+}, 807 \mathrm{mg} / \mathrm{l} \mathrm{Na}^{+}, 110 \mathrm{mg} / 1 \mathrm{~K}^{+}$.

The autoclaves were connected with $\mathrm{CO}_{2}$ tanks by supply lines at a pressure of $6 \mathrm{MPa}$. The experiment lasted for 20 months at room temperature $\left(20-25^{\circ} \mathrm{C}\right)$.

\subsection{Methods}

Mineralogical, petrographic, structural, and textural analyses of rock samples were performed before and after the experiment.

For microscopic characterization in polarized transmitted light as well as quantitative point-counting modal analysis, a JENALAB Karl Zeiss Jena petrographic microscope was used with the magnifications of $2.5 \times 0.05 ; 10 \times 0.25 ; 50 \times 0.08$.

The scanning electron microcopy analyses were carried out by an FEI Quanta 250 FEG SEM microscope equipped with an EDS-EDAX energy dispersion spectrometer for elemental microanalysis.

Powder X-ray diffraction analysis (XRD) was performed using a Philips X'pert APD $\mathrm{X}$-ray diffractometer with a PW 3020 goniometer and copper lamp, as well as a graphite monochromator. The angular range from 5 to $652 \theta$ was used. The diffraction data were processed by Philips X'Pert software. Identification of mineral phases was based on the JCPDS - ICDD database. Additionally, diffraction patterns of the clay fraction were obtained in the angular range of 5 to $352 \theta$. The clay fraction was separated by sedimentation, and oriented preparations were used for XRD analysis. The analysis was run on air-dry samples, ethylene glycol saturated samples (by evaporation methods over a period of 12 hours at $60^{\circ} \mathrm{C}$ ), and samples calcined at $560^{\circ} \mathrm{C}$ for one hour. For differential thermal analysis, a TA Instruments SDT 2960 (differential scanning calorimeter type DSC 2010, TA Instruments) was used for simultaneous thermogravimetric and differential thermal analysis (TG, DTG, DTA).

Measurements of mass changes were made in the range of $0-100 \mathrm{mg}$ with a precision of $6-10 \mathrm{~g}$, and the measurement temperature in the range from $0-1000^{\circ} \mathrm{C}$ with a precision of $0.01^{\circ} \mathrm{C}$. The heat was measured with a precision of $0.01 \mathrm{~J}$.

The textural parameters were determined using an ASAP 2020 Micromeritics analyzer. Specific surface area, pore size, and pore radius with respect to pore distribution were determined based on the shape of the nitrogen gas adsorption/desorption isotherm at $-196.15^{\circ} \mathrm{C}$. Prior to the analysis, samples were degassed under strictly controlled conditions at a temperature of $250^{\circ} \mathrm{C}$ for $24 \mathrm{~h}$ and at a reduced pressure of $10^{-3} \mathrm{hPa}$.

Specific surface area was determined based on Braunauer-Emmett-Teller's multilayer adsorption (BET) theory (Gregg and Sing 1982), at $\mathrm{p} / \mathrm{p}_{0}$ between 0.06 and 0.3 
$\left(\mathrm{p}, \mathrm{p}_{0}\right.$ - equilibrium pressure and saturation pressure of nitrogen). The pore volumes $\left(\mathrm{V}_{\mathrm{p}}\right)$ were determined from the volume of adsorbed nitrogen at pressure $\mathrm{p} / \mathrm{p}_{0}=0.98$.

The diameters of the pores $\left(D_{p}\right)$ were calculated according to the equation $D_{p}=$ $=4 \mathrm{~V}_{\mathrm{p}} / \mathrm{S}_{\mathrm{BET}}$. Distribution of pore volumes (assigned as $\mathrm{R}_{\mathrm{p}}$ ) was calculated using a general isotherm equation based on the combination of a modified Kelvin equation and a statistic thickness of adsorbed film (Wdowin, Gruszecka 2012; Wdowin et al. 2013).

\section{Results}

\subsection{Petrographic-mineralogical characteristic}

\section{Sandstone}

Zaosie 2 - depth $838.10 \mathrm{~m}$

The analyzed rock is representative of medium- to coarse-grained sandstone (grain size from 300 to $800 \mu \mathrm{m}$ ) showing unoriented and highly porous structure. The pores up to $1 \mathrm{~mm}$ in size constitute up to $28.6 \%$ of the rock volume. The grains are medium sorted and poorly rounded. The grain skeleton consists of quartz $(55.2 \%)$ and feldspar (7.2\%), lithoclasts $(1.4 \%)$ with a small amount of micas (biotite $0.4 \%$, muscovite $0.6 \%$ ), amphibole, and carbonates. Accessory minerals (a total of $0.8 \%$ ) are zircon, titanite, apatite, opaque minerals, and metal oxides and/or hydroxides of iron. A relatively small amount of the matrix (5.8\%) is composed of kaolinite dominated clay. Locally, the cement has a clay-ferruginous nature. The test sandstone, according to the classification of Pettijohn et al. (1972), is subarkose arenite $(\mathrm{Q}=86.5 \%, \mathrm{~F}=11.3 \%, \mathrm{~L}=2.2 \%)$.

The thermogravimetric curve of raw sandstone before the experiment (Fig. 1) shows an endothermic reaction at a temperature of $573^{\circ} \mathrm{C}$, resulting from the transition of low-temperature quartz to high temperature quartz.

The experiment resulted only in minor alterations of the rock. The porosity determined with point-counting decreased from $28.6 \%$ to $22.4 \%$. The pores were smaller, which may result from redistribution of the clay matrix or precipitation of new mineral phases (kaolinite) in the pores. After the experiment, there was a smaller amount of cement (matrix type) in the sample, which may result from the dissolution of some minerals (kaolinite, feldspar). Corroded feldspar grains are observed with the SEM both in the raw and altered sample, making it difficult to distinguish which reactions of this type result solely from the experiment. A small amount of halite is observed which results from the brine saturation, and is a product of the experiment.

Thermogravimetric curves of the sandstone before and after the experiment are very similar, confirming that very little changes result from the interaction of this rock with $\mathrm{CO}_{2}$-saturated brine. Only a slight decrease in the total weight is observed from the TG curve after the experiment, which can be related to the dissolution of some mineral phases. 


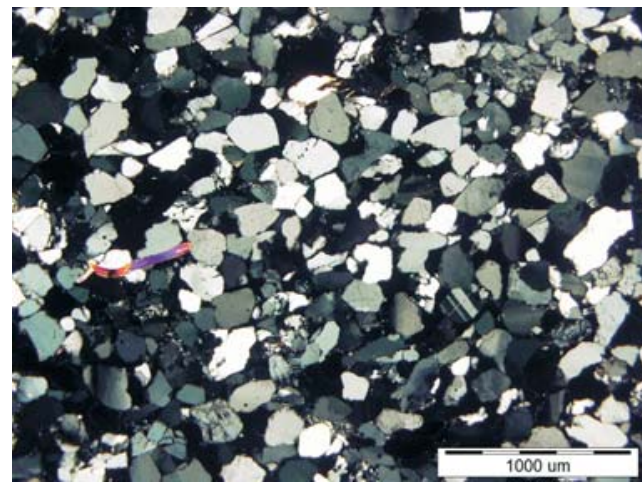

Porous subarkose arenite before the experiment. Optical microscope, crossed polars

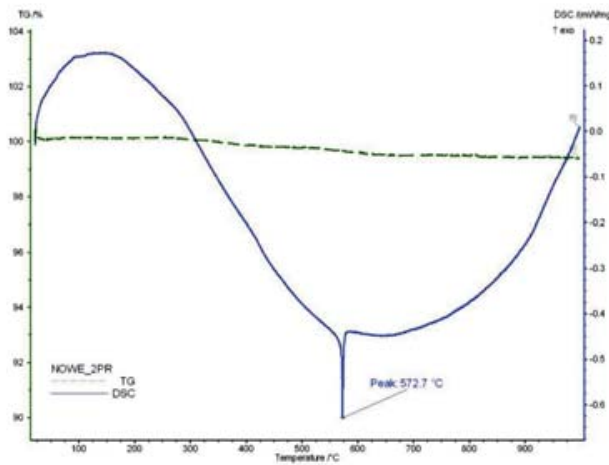

Thermogravimetric curve of the sandstone before the experiment

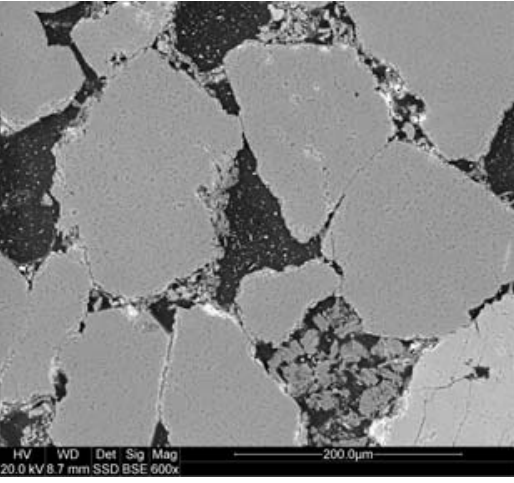

Kaolinite in the matix, SEM microphotograph, before the experiment

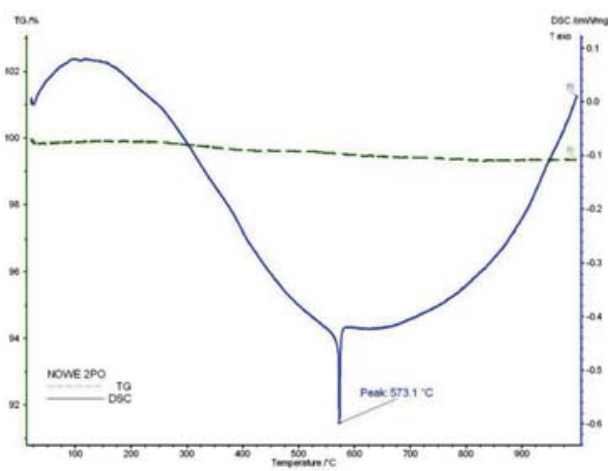

Thermogravimetric curve of the sandstone after the experiment

Fig. 1. The results of microscopic and thermogravimetric analysis of Zaosie 2 sandstone, depth $838.10 \mathrm{~m}$

Rys. 1. Obrazy mikroskopowe i krzywe analiz termicznych piaskowca z Zaosia 2, głębokość 838,10 m

\section{Sandstone}

Buków 2 - depth $1435.50 \mathrm{~m}$

The analyzed rock constitutes medium to very fine grained sandstone (particle size from 60 to $500 \mu \mathrm{m}$ ), slightly porous (porosity $11.4 \%$, pore size about $600 \mu \mathrm{m}$ ). The skeleton consists mostly of poorly rounded, medium sorted grains of quartz (65.2\%) and feldspar (8.6\%). Small amounts of micas (biotite 0.6 , muscovite $0.6 \%$ ) and lithoclasts $(0.8 \%)$ are present too. Accessory minerals $(1 \%)$ are represented by zirconium, apatite, opaque minerals, as well as oxides and hydroxides of Fe. The cement is mainly composed of carbonate phases and is mostly of a basal-porous nature (9.2\%). Smaller amounts of the matrix are a type of cement $(2.8 \%)$ consisting of clay minerals (kaolinite forming the characteristic, fan-shaped and column forms) as well as aleuritic clastic material. Based on 
the modal content of quartz, feldspars, and lithoclasts $(\mathrm{Q}=87.4 \%, \mathrm{~F}=11.5 \%, \mathrm{~L}=1.1 \%)$, the rock is classified as subarkose arenite (Pettijohn et al. 1972).

Thermogravimetric analysis of the rock before the experiment (Fig. 2) revealed an endothermic reaction at $250^{\circ} \mathrm{C}$ resulting from the presence of $\mathrm{Fe}$ oxides and hydroxides. The strong endothermic effect at $573^{\circ} \mathrm{C}$ results from low-temperature quartz transitioning to high temperature quartz, followed by an endothermic reaction at $637^{\circ} \mathrm{C}$ indicating the presence of carbonate minerals or clay minerals other than kaolinite or illite.

As a result of the experiment, the porosity of the sandstone increased from $11.4 \%$ to $19.4 \%$, and the amount of cement, particularly carbonate, decreased. The modal content of feldspars decreased from $8.6 \%$ to $4.6 \%$ and the content of kaolinite and illite decreased below the detection limit of powder XRD. Thermal effects at $250^{\circ} \mathrm{C}$ and $637^{\circ} \mathrm{C}$ do not appear on the DTA curve after the experiment, indicating the removal of Fe oxides and hydroxides and some clays.

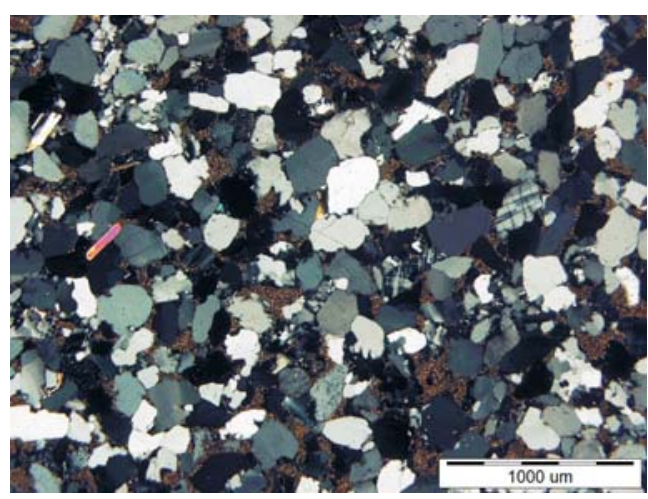

Subarkose arenite before the experiment. Optical microcsope, crossed polars

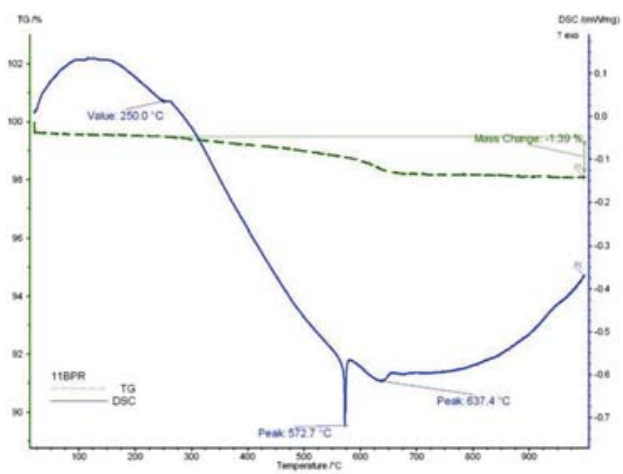

Thermogravimetric curve of the sandstone before the experiment

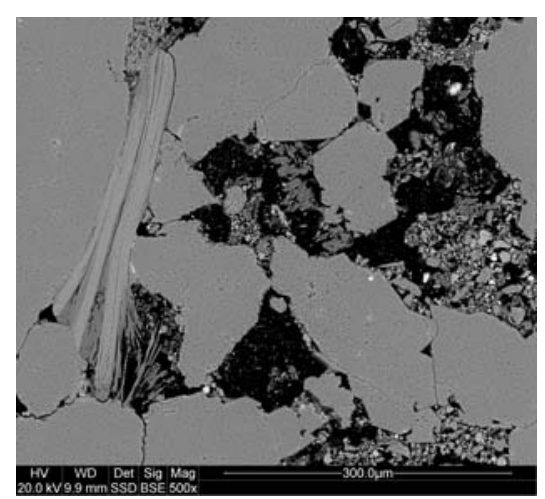

Mica and matrix in pores, SEM microphotograph, before the experiment

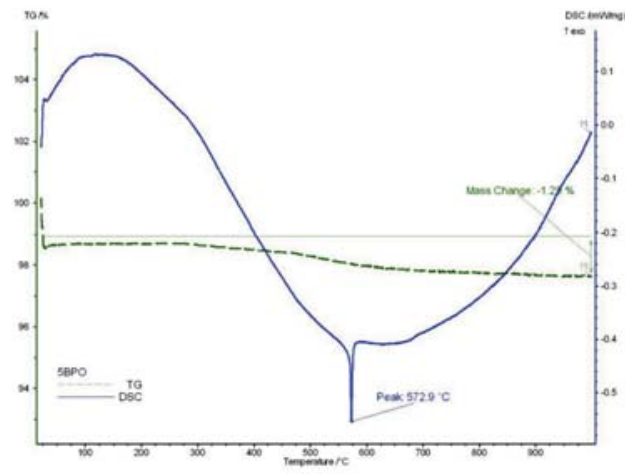

Thermogravimetric curve of the sandstone after the experiment

Fig. 2. The results of microscopic and thermogravimetric analysis of sandstone from Buków 2, depth $1435.50 \mathrm{~m}$

Rys. 2. Obrazy mikroskopowe i krzywe analiz termicznych piaskowca z Bukowa 2, głębokość 1435,50 m 


\section{Claystone}

Zaosie 2 - depth $912.40 \mathrm{~m}$

The sealing rock from Zaosie 2 is of aleuritic fraction. It is well sorted with poorly roundned grains between $20-30 \mu \mathrm{m}$ in size. Sporadically, single, larger grains of a size between 100 and $450 \mu \mathrm{m}$ are observed. The claystone exhibits a layered structure. Individual layers differ in the proportion of quartz to clays and micas. Microscopically apparent pores (up to $125 \mu \mathrm{m}$ in size) are sparse.

The mineral composition is dominated by quartz and micas (biotite, muscovite), as well as clay minerals (mainly as matrix). Quartz grains are poorly rounded. Micas are often altered by illitization and chloritization. Small amounts of K-feldspar and kaolinite are also observed. The presence of kaolinite, illite, and montmorillonite is confirmed by XRD (Fig. 3). In a separated clay fraction (Fig. 3), kaolinite, illite, and montmorillonite are observed. Additionally, opaque minerals and iron oxides and/or hydroxides occur in the rock skeleton in the form of irregular grains scattered throughout the rock. Accessory minerals include zircon and rutile. Reviewing the thermogravimetric curve of the raw claystone before the experiment (Fig. 3) shows more than a 5\% mass loss and an endothermic effect at a temperature of $573^{\circ} \mathrm{C}$, which takes place during the transition of low-temperature quartz to high temperature quartz.

In the rock after the experiment, there was no change (except for a very small amount of halite precipitated from the brines) in either the mineral composition, or in the share of the pores. No corrosion of feldspars or micas was observed. Chlorite presence in the XRD pattern after the experiment is attributed to the inhomogeneity of the rock (distinct samples were analyzed).

Thermogravimetric curves before and after the experiment are very similar, indicating no significant changes after the experiment. From TG curves before and after the experiment, a loss in weight is observed between $300-700^{\circ} \mathrm{C}$, which is probably related to dehydroxylation of clay minerals present in the rock sample.

\section{Mudstone}

Buków 2 - depth $1436.00 \mathrm{~m}$

The sealing rock from Buków 2 represents poorly sorted aleuritic to pelitic mudstone with poorly rounded grains and laminated structure. The individual laminas differ in grain size, color, and the content of detrital organic material. Fine-grained laminas $(<40 \mu \mathrm{m})$ are brown in color and rich in organic matter, while coarse layers (grains from 40 to $120 \mu \mathrm{m}$ ) are colorless or light brown and contain very few organics. Very few pores are 40-90 $\mu \mathrm{m}$ in size.

The mineral composition is dominated by quartz, mica, clay minerals (mainly kaolinite and illite), and detrital organic matter. Subordinate feldspars mainly consist of twinned plagioclases. X-ray diffraction of the clay fraction allowed for identification of kaolinite, illite, montmorillonite, and chlorite. Quartz grains form poorly rounded grains. Micas (mostly muscovite, seldom biotite) often form aggregates. Kaolinitization, illitization, and chloritization of micas are apparent. In addition, the rock contains opaque minerals and 
oxides and/or hydroxides of iron. Zircon is an accessory mineral. The thermogravimetric curve (Fig. 4) indicates an exothermic reaction at a temperature of $226^{\circ} \mathrm{C}$ resulting from the burning of organic matter. An endothermic effect due to the loss of water from clay minerals

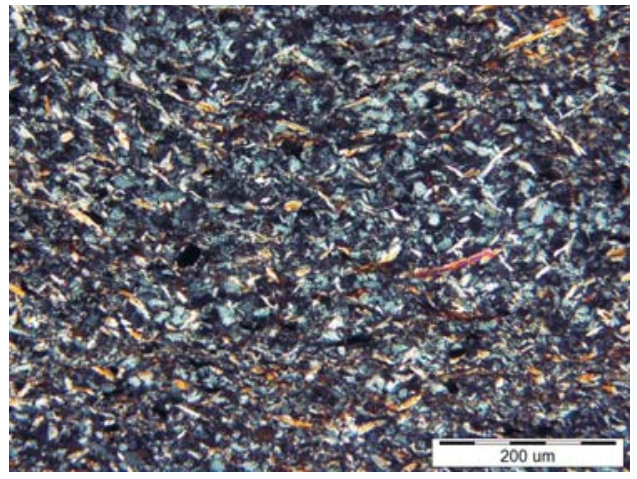

Claystone before the experiment. Optical micsroscope, crossed polars
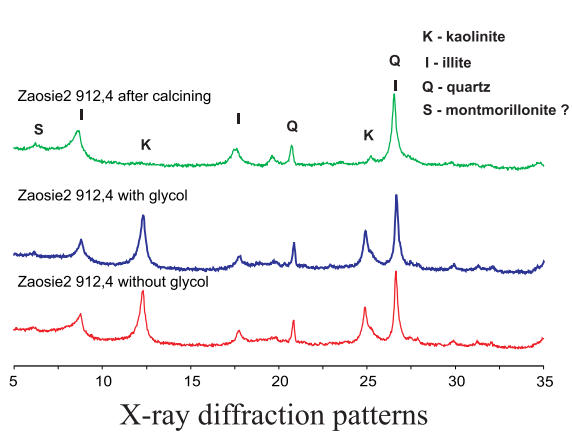

of clay fraction before the experiement

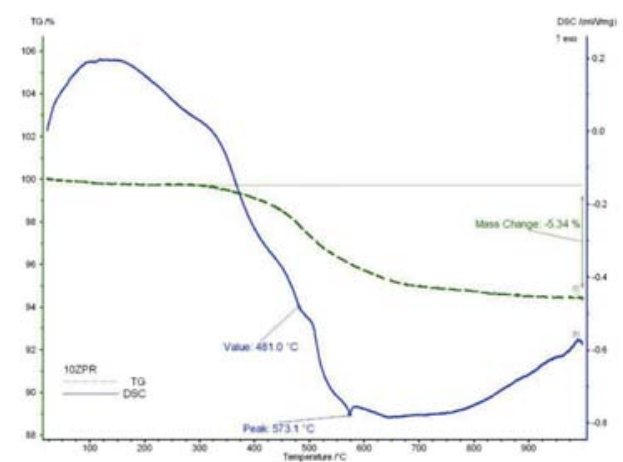

Thermogravimetric curve of claystone before the experiment

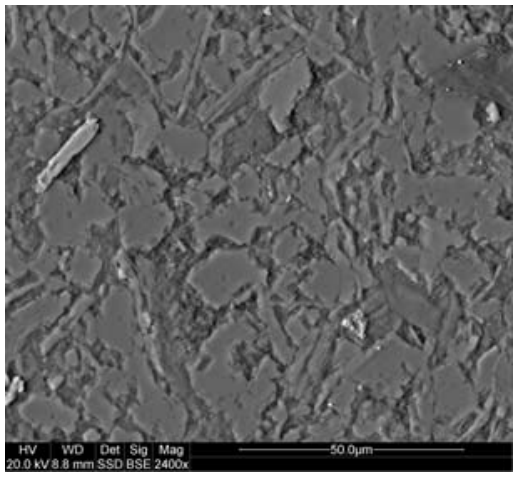

SEM microphotograph of claystone before the experiment

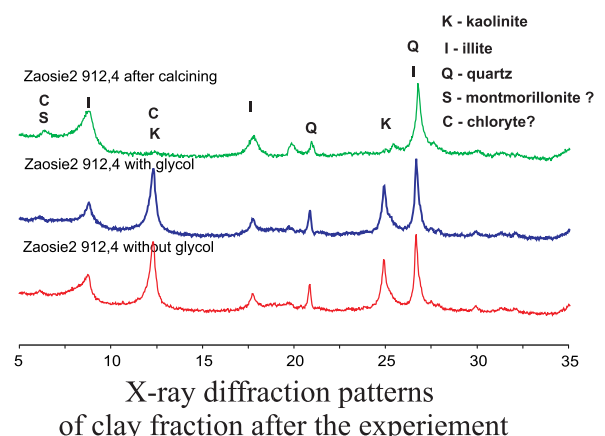

of clay fraction after the experiement

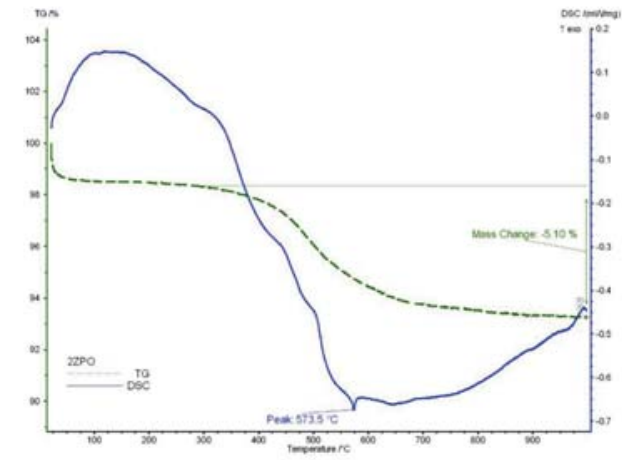

Thermogravimetric curve of claystone after the experiment

Fig. 3. The results of microscopic, X-ray diffraction, and thermogravimetric analysis of claystone from Zaosie 2, depth $912.40 \mathrm{~m}$

Rys. 3. Obrazy mikroskopowe oraz krzywe dyfrakcyjne i termiczne iłowca z Zaosia 2, głębokość 912,40 m 
is apparent at $483^{\circ} \mathrm{C}$. Other endothermic effects are noted at $573^{\circ} \mathrm{C}$ (transition of low-temperature quartz into high temperature quartz), $646^{\circ} \mathrm{C}$ (presence of clay minerals other than kaolinite and illite, or some carbonates), and $914^{\circ} \mathrm{C}$ (decomposition of carbonates).

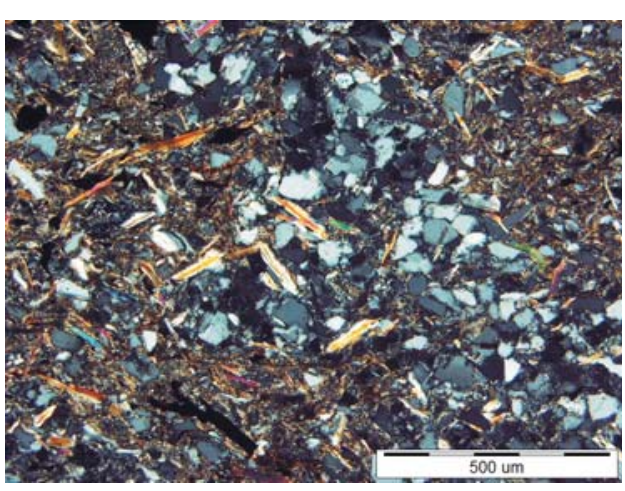

Mudstone before the experiment. Optical microscepe, crossed polars

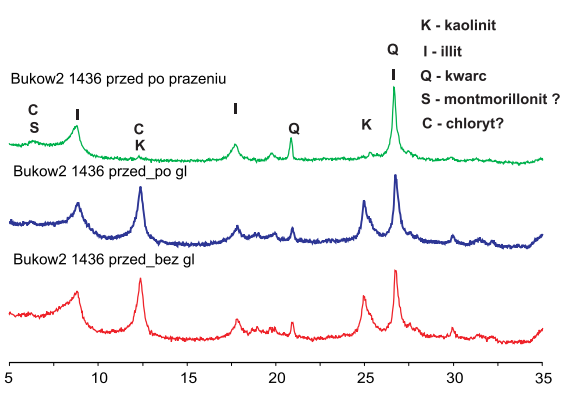

X-ray diffraction pattern of clay fraction before the experiement

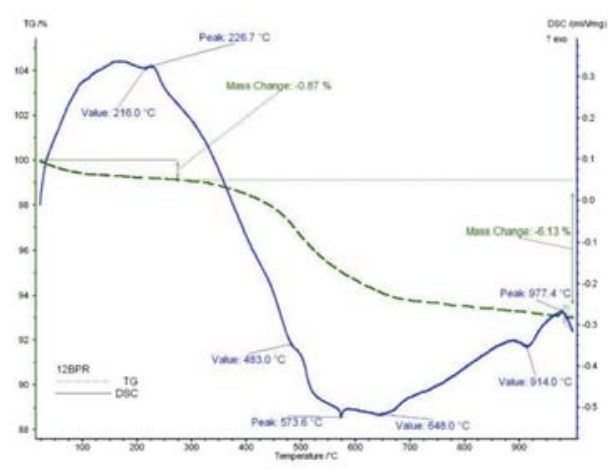

Thermogravimetric curve of mudstone before the experiment

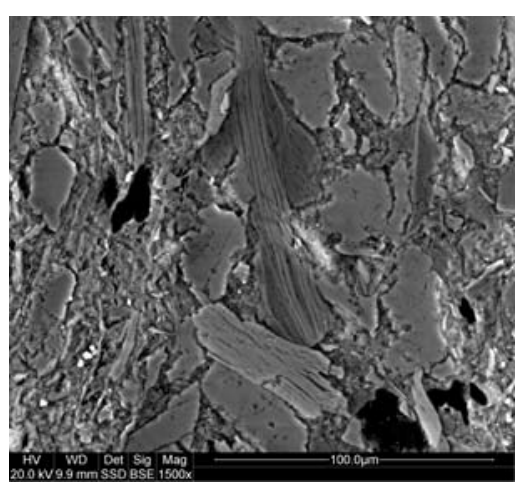

SEM microphotograph of mudstone before the experiment. 1,2 - micas, 3 - quartz

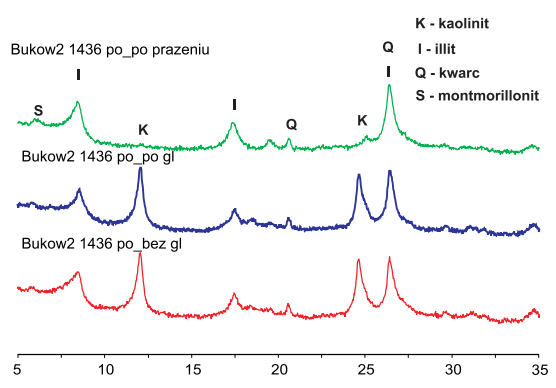

X-ray diffraction pattern of clay fraction after the experiement

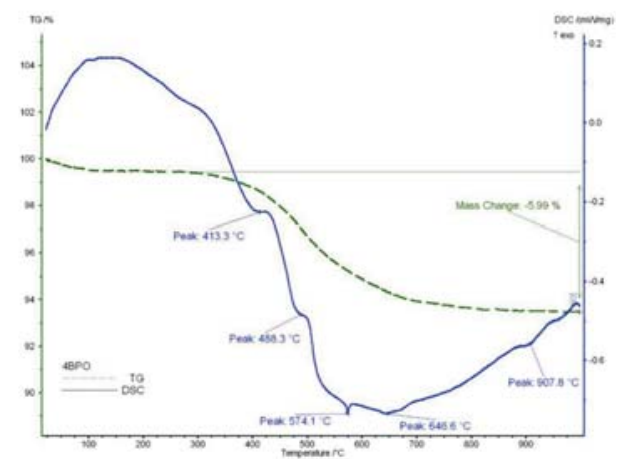

Thermogravimetric curve of mudstone after the experiment

Fig. 4. The results of microscopic, X-ray diffraction, and thermogravimetric analysis of mudstone from Buków 2, depth $1436.00 \mathrm{~m}$

Rys. 4. Obrazy mikroskopowe oraz krzywe dyfrakcyjne i termiczne mułowca z Bukowa 2, głębokość 1436,00 m 
An increase in pore size was observed in the mudstone after the experiment. Chlorite is no longer apparent in the diffraction pattern of the clay fraction (Fig. 4). The thermogravimetric curve of the sample after the experiment does not reveal an exothermic peak at $226^{\circ} \mathrm{C}$, but shows an endothermic reaction associated with the dehydratation of hydroxides (goethite) at $413^{\circ} \mathrm{C}$.

\subsection{Textural characteristic}

In order to determine the surface properties of the studied rocks, a number textural analyses were carried out including BET surface area and pore size distribution (micro-, meso-, and macropores), which have a significant impact on the storage properties and may be altered by $\mathrm{CO}_{2}$-brine-rock interactions.

\section{Sandstones}

Zaosie 2 - depth $838.10 \mathrm{~m}$

Very small adsorption, low surface area, and the shape of isotherms allow for the conclusion that the porous space in this sandstone is dominated by macropores. The total volume of the micro- and mesopore is low (less than $0.01 \mathrm{~cm}^{3} / \mathrm{g}$ ). Pore diameters determined using the $\mathrm{BJH}(\mathrm{dV} / \mathrm{dD} \mathrm{f}(\mathrm{D}))$ may not be reliable due to the low fraction of pores in the range of 1-300 nm (Table 2) These results indicate that the examined sandstone has a negligible and inhomogeneous mesoporous nature and bimodal pore size distribution. The experiment resulted in a small alteration in the porosity by changing the ratio of the large to the small pores (Fig. 5).

TABLE 2

Comparison of surface area and pore parameters of tested sandstones before and after the experiments

Porównanie powierzchni właściwej oraz objętość i wielkość porów badanych piaskowców przed i po eksperymencie

\begin{tabular}{||l|c|c|c|c|}
\hline & $\mathrm{S}_{\mathrm{BET}}\left[\mathrm{m}^{2} / \mathrm{g}\right]$ & $\mathrm{V}_{\mathrm{p}}\left[\mathrm{cm}^{3} / \mathrm{g}\right]$ & $\mathrm{D}[\mathrm{nm}]$ & $\mathrm{D}[\mathrm{nm}] \mathrm{BJH}$ \\
\hline \hline Zaosie 2 - 838.10 m before & 0.88 & 0.0030 & 9.26 & $11.22 ; 15,67$ \\
\hline Zaosie 2 - 838.10 m after & 0.81 & 0.0028 & 9.67 & $11.36 ; 19.70$ \\
\hline Buków 2-1435.50 m before & 0.76 & 0.0039 & 13.24 & $14.33 ; 19.62$ \\
\hline Buków 2-1435.50 m after & 1.34 & 0.0045 & 10.11 & $4.03 ; 9.00 ; 17.42$ \\
\hline
\end{tabular}

$307 \mathrm{~S}_{\mathrm{BET}}$ - surface area $\left[\mathrm{m}^{2} / \mathrm{g}\right]$,

$\mathrm{V}_{\mathrm{p}}$ - total volume of pores $\left[\mathrm{cm}^{3} / \mathrm{g}\right]$,

$\mathrm{D}$ - average pore diameter $[\mathrm{nm}]$,

$\mathrm{D}_{\mathrm{BJH}}$ - pore diameter determined by BJH method. 


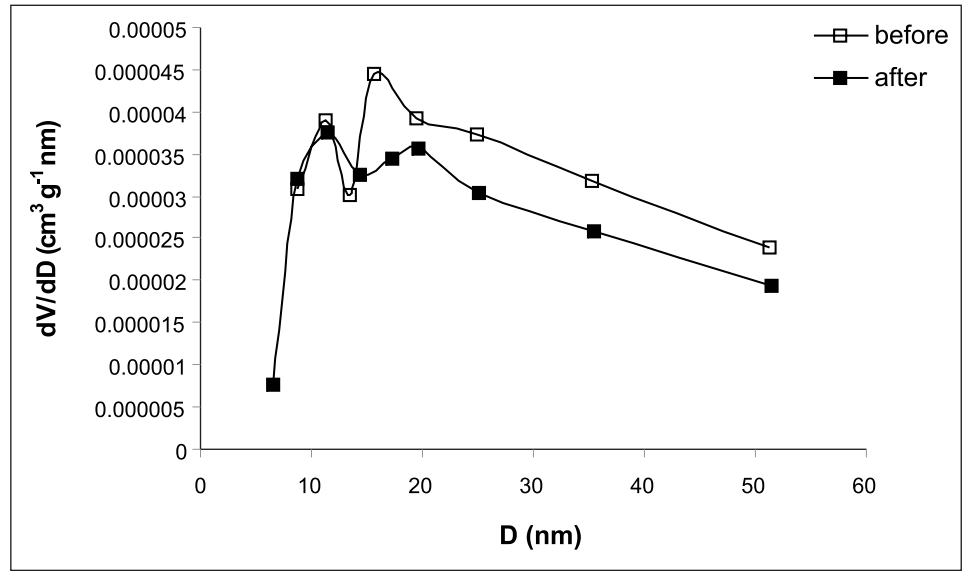

Fig. 5. Pore size distribution for sandstone from Zaosie 2, depth $838.10 \mathrm{~m}$

Rys. 5. Rozkład wielkości porów dla piaskowca z otworu Zaosie 2, głębokość 838,10 m

Buków 2 - depth $1435.50 \mathrm{~m}$

Low adsorption of micro- and mesopores, the small value of the specific surface area, and the shape of the isotherm indicate that the sandstone is macroporous in nature. The total volume of micro- and mesopores is below $0.01 \mathrm{~cm}^{3} / \mathrm{g}$ (Table 2). The graph illustrating the pore volume distribution (Fig. 6) relative to the diameter, after the experiment, clearly shows the presence of three maxima. The first one at $4.03 \mathrm{~nm}$ is narrow while the other two (at 9.00 and $17.42 \mathrm{~nm}$ ) are broad. The narrow maximum is not apparent on the pore size distribution curve of the raw sandstone. This indicates quite a significant change in pore size distribution resulting from the interaction between the sandstone and $\mathrm{CO}_{2}$-saturated brine.

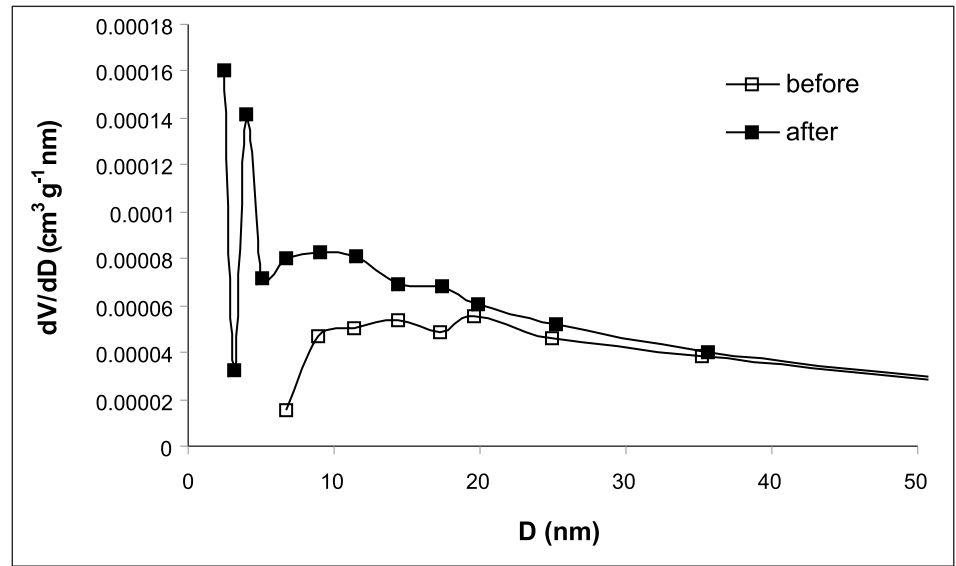

Fig. 6. Pore size distribution for sandstone from Buków 2, depth $1435.50 \mathrm{~m}$

Rys. 6. Rozkład wielkości porów dla piaskowca z otworu Buków 2, głębokość 1435,50 m 


\section{Claystone}

Zaosie 2 - depth $912.40 \mathrm{~m}$

This mesoporous rock has low surface area and low porosity (Vp of about $0.02 \mathrm{~cm}^{3} / \mathrm{g}$, Table 3). It is characterized by a narrow and homogeneous pore size distribution (Fig. 7). The effective diameter of pores is about $4 \mathrm{~nm}$. The experiment did not affect significantly the porous structure of the sample. Based on the analysis, it can be concluded that the experiment slightly reduced the surface area (from 9.31 to $8.33 \mathrm{~m}^{2} / \mathrm{g}$ ), and did not affect the value of the effective diameter.

TABLE 3

Comparison of surface area and pore parameters of the tested sealing rocks before and after the experiments

TABELA 3

Porównanie powierzchni właściwej oraz objętość i wielkość porów badanych skał uszczelniających przed i po eksperymencie

\begin{tabular}{||l|c|c|c|c||}
\hline & $\mathrm{S}_{\mathrm{BET}}\left[\mathrm{m}^{2} / \mathrm{g}\right]$ & $\mathrm{V}_{\mathrm{p}}\left[\mathrm{cm}^{3} / \mathrm{g}\right]$ & $\mathrm{D}[\mathrm{nm}]$ & $\mathrm{D}[\mathrm{nm}] \mathrm{BJH}$ \\
\hline \hline Zaosie 2 $-912.40 \mathrm{~m}$ before & 9.31 & 0.0248 & 9.49 & 4.05 \\
\hline Zaosie 2 - 912.40 m after & 8.33 & 0.0200 & 8.65 & 4.05 \\
\hline Buków 2 - 1436.00 m before & 17.22 & 0.0215 & 5.67 & no peak \\
\hline Buków 2 - 1436.00 m after & 21.29 & 0.0368 & 6.64 & 4.06 \\
\hline
\end{tabular}

$\mathrm{S}_{\mathrm{BET}}$ - surface area $\left(\mathrm{m}^{2} / \mathrm{g}\right)$

$\mathrm{V}_{\mathrm{p}}$ - total pore volume $\left(\mathrm{cm}^{3} / \mathrm{g}\right)$,

$\mathrm{D}$ - average pore diameter $(\mathrm{nm})$,

$\mathrm{D}_{\mathrm{BJH}}-$ pore diameter determined by BJH method.

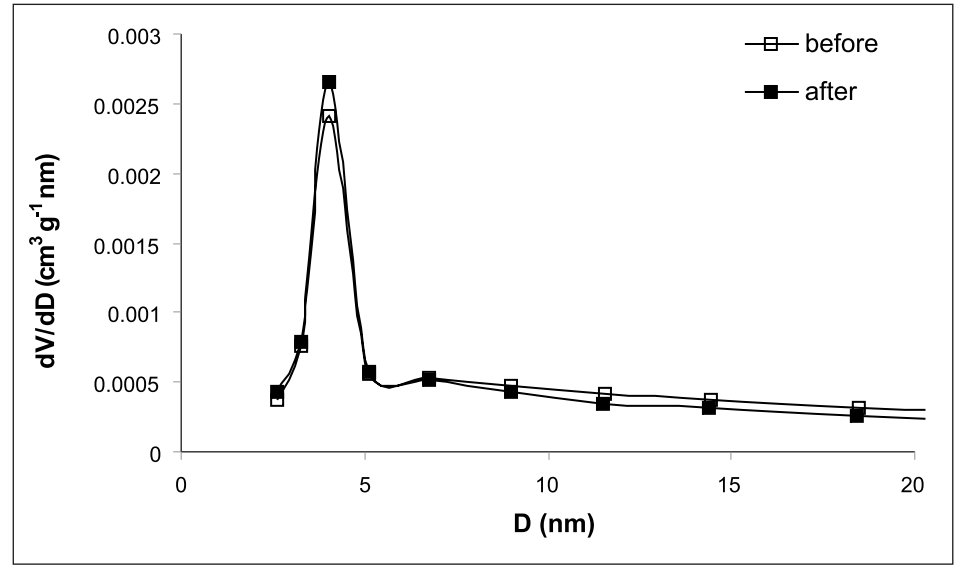

Fig. 7. Pore size distribution for claystone from Zaosie 2, depth $912.40 \mathrm{~m}$

Rys. 7. Rozkład wielkości porów dla iłowca z otworu Zaosie 2, głębokość 912,40 m 


\section{Mudstone}

Buków 2 - depth $1436.00 \mathrm{~m}$

This rock is classified as mesoporous material. The experiment resulted in significant changes in its porosity. Surface area increased from 17.22 to $21.29 \mathrm{~m}^{2} / \mathrm{g}$ (Table 3 ). The pore size distribution graph of the raw material shows no peaks, indicating high heterogeneity of the pore size (Fig. 8). After the experiment, a strong narrow peak at the value of $4.06 \mathrm{~nm}$ is observed, representing the formation of mesopores as a result of a reaction with the $\mathrm{CO}_{2}$-saturated brine. This is also apparent on the isotherms (data not shown). The isotherm of the raw material is characterized by larger hysteresis (wider pores) and an upward trend (constant adsorption with increasing $\mathrm{p} / \mathrm{p}_{0}$ ). The isotherm of the mudstone after the experiment is type I, rising slightly upwards (a gradual increase in adsorption with increasing $\left.\mathrm{p} / \mathrm{p}_{0}\right)$, with a hysteresis of $\mathrm{H} 4$ indicating narrow pores.

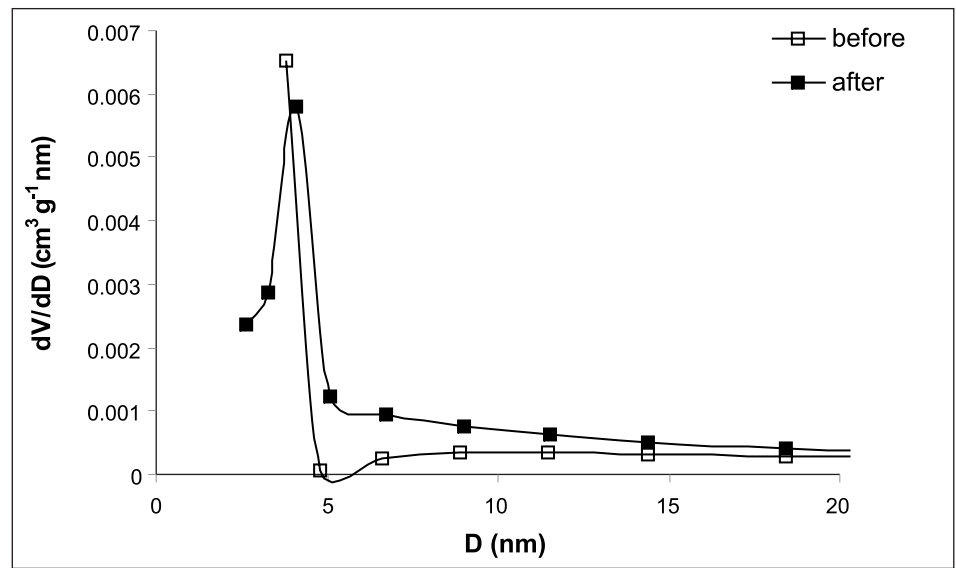

Fig. 8. Pore size distribution for mudstone from Buków 2, depth $1436.00 \mathrm{~m}$

Rys. 8. Rozkład wielkości porów dla mułowca z otworu Buków 2, głębokość 1436,00 m

\section{Summary and conclusion}

The preceding experiments simulated the system which could potentially be used for the sequestration and underground storage of $\mathrm{CO}_{2}$. The rocks used in the experiment included reservoir sandstones and sealing rocks (claystones and mudstones) from drill cores Zaosie 2 and Buków 2. A comparison of changes resulting from the 20-month experiment of interactions between $6 \mathrm{MPa} \mathrm{CO}_{2}$-saturated brine and the rocks indicates a relatively small changes in the rocks' composition and texture. Similar results of long term experiments were obtained by other authors, e.g. Fischer et al. (2010), Liu et al. (2012), Rimmelé et al. (2009), Wollenweber et al. (2009). This phenomenon is a result of the nature of the rocks as well 
as partly associated with the relatively low pressure and low temperature of the experiment. The studied rocks contain only small amounts of potentially reactive materials (carbonates, K-feldspar, kaolinite).

The primary alterations observed in sandstones include changes in porosity. Reservoir sandstone from Zaosie 2 shows a small decrease in porosity which may actually result from the precipitation of halite after the experiment. Similar results were described by Kaszuba et al. (2003). The solution's interaction with the reservoir sandstone from Buków 2 resulted in an increase in porosity. This is probably caused by partial dissolution of minerals within the mineral skeleton and cement: feldspars, carbonates, and iron oxides and hydroxides. This is consistent with a decrease in the feldspar content from 8.6 to $4.5 \%$, and a decrease in the carbonate cement from 9.2 to $1 \%$. The lack of thermal effect at 250 and $637^{\circ} \mathrm{C}$ in the thermogravimetric curve of the rock after the experiment is consistent with this interpretation. SEM imaging reveals corroded feldspars and autigenic kaolinites in the pores. Such features were described as a result of similar experiments (Liu et al. 2012). These alterations, however, were also observed locally in the raw material before the experiment, which makes the interpretation inconclusive.

A similar situation is observed within the sealing rocks: the porosity of the Zaosie 2 claystone decreased after a time, and the porosity of the Buków 2 mudstone increased. This is a result of the dissolution or precipitation of mineral constituents. It should also be taken into account that the identification of the changes in porosity comes only with the textural test results because the point-count analysis of such a fine-grained material was impossible.

This study represents one stage in the determination of the effects of rock-brine- $\mathrm{CO}_{2}$ interactions in order to assess the suitability of the studied rocks for carbon dioxide storage. The presented examinations show changes in porosity resulting from the dissolution and precipitation of various mineral phases. However, to get to know the direction of the reaction in the rock matrix (dissolution/precipitation), the next step in the research will be a detailed analysis of the brines before and after the experiment, as well as geochemical modeling that is important in assessing the suitability of geological structures for geological sequestration of $\mathrm{CO}_{2}$ (Labus et al. 2010).

The project was funded by the National Science Centre, allocated according to decision No. DEC-2011/ /03/B/ST10/04340

\section{REFERENCES}

Baran et al. 2013 - B aran P., Cyganki ewicz J., Zarębska K., 2013 - Carbon dioxide sorption on Polish ortholignite coal in low and elevated pressure, Journal of $\mathrm{CO}_{2}$ Utilization (in press), http://dx.doi.org/10.1016/j.jcou.2013.09.003

Bachu et al. 1994 - B a chu S., Gunter W.D., P erkins E.H., 1994 - Aquifer disposal of $\mathrm{CO}_{2}$ : hydrodynamic and mineral trapping. Energy Conversion and Management 35, pp.269-279. 
Fischer et al. 2013 - F i s cher S., Li e b s cher A., L u c i a M., H e cht L. and the Ketzin Team, 2013 - Reactivity of sandstone and siltstone samples from the Ketzin pilot $\mathrm{CO}_{2}$ storage site - Laboratory experiments and reactive geochemical modeling. Environmental Earth Sciences, DOI 10.1007/s12665-013-2669-4.

Fischer et al. 2013 - F i s cher S., Li e b s cher A., W and re y M., the CO2SING group, $2010-\mathrm{CO}_{2}$-brine-rock interaction - First results of long-term exposure experiments at in situ $\mathrm{P}-\mathrm{T}$ conditions of the Ketzin $\mathrm{CO}_{2}$ reservoir. Chemie der Erde - Geochemistry 70, S3, pp. 155-164.

Gunter et al. 1993 - Gunter W.D., Perk in s E.H., McC an n T.J., 1993 - Aquifer disposal of $\mathrm{CO}_{2}$-rich gases: reaction design for added capacity. Energy Conversion and Management 34, pp. 941-948.

Kaszuba et al. 2003 - K a s zu b a J.P., J a n e cky D.R., S n ow M.G., 2003 - Carbon dioxide reaction processes in a model brine aquifer at $200^{\circ} \mathrm{C}$ and 200 bars: implications for geologic sequestration of carbon. Applied Geochemistry 18 (7), pp. 1065-1080.

Labus et al. 2010 - Labu s K., T arkow ski R., W d ow in M., 2010 - Assesment of $\mathrm{CO}_{2}$ sequestration capacity based on hydrogeochemical model of Water-Rock interactions in the potential storage site within the Bełchatów area (Poland). Mineral Resources Management (Gospodarka Surowcami Mineralnymi) t. 26, z. 2, pp. 69-84.

Liu et al. - Liu F., Lu P., Griffith C., Hedges S.W., Soong Y., Hellevang H., Zhu Ch., 2012 $\mathrm{CO}_{2}$-brine-caprock interaction: Reactivity experiments on Eau Claire shale and a review of relevant literature. International Journal of Greenhouse Gas Control 7, pp. 153-167.

Marek et al. 2011 - Marek S., D zie wi ńska L., T arkowski R., 2011 - The possibilities of underground $\mathrm{CO}_{2}$ storage in the Zaosie Anticline. Mineral Resources Management (Gospodarka Surowcami Mine- ralnymi) t. 22 , z. 4, pp. $89-107$.

Rimmelé et al. 2009 - Rimmelé G., Barlet-Gouédard V., Renard F., 2009 - Evolution of the Petrophysical and Mineralogical Properites of Two Reservoir Rocks Under Thermodynamic Conditions Relevant for $\mathrm{CO}_{2}$ Geological Storage at $3 \mathrm{~km}$ Depth. Oil Gas Sciences and Technology - Rev. IFP 65, 4, pp. $565-580$.

Shukla et al. 2010 - S huk la R., R a n j it th P., et al., 2010 - A review of studies on $\mathrm{CO}_{2}$ sequestration and caprock integrity. Fuel 89 (10), pp. 2651-2664.

Tarkowski R., Wdowin M., 2011 - Petrophysical and Mineralogical Research on the Influence of $\mathrm{CO}_{2}$ Injection on Mesozoic Reservoir and Caprocks from the Polish Lowlands. Oil \& Gas Science and Technology - Rev. IFP Energies nouvelles, Vol. 66, No. 1, pp. 137-150.

Tarkowski et al. 2011 - Tarkowski R., Wdowin M., Labus K., 2011 - Results of mineralogic-petrographical studies and numerical modeling of water-rock- $\mathrm{CO}_{2}$ system of the potential storage site within the Belchatow area (Poland). Energy Procedia vol. 4, pp. 3450-3456.

Wang et al. 2013 - Wang T., Wang H., Zhang F., Xu T., 2013 - Simulation of $\mathrm{CO}_{2}$-water-rock interactions on geologic $\mathrm{CO}_{2}$ sequestration under geological conditions of China. Marine Pollution Bulletin doi.org/10.1016/j.marpolbul.2013.08.014.

W d ow in M., T a r k ow sk i R., 2010 - Charakterystyka mineralogiczno-petrograficzna jurajskich skał struktury Budziszewice (rejon Bełchatowa) dla geologicznej sekwestracji $\mathrm{CO}_{2}$. Przegląd Górniczy 5, pp. 56-64

Wdowin et al., 2013 - Wdowin M., T ark ow sk i R., F r a nu s W., 2013 - Supplementary studies of textural and mineralogical changes in reservoir and cap rocks from selected potential sites suitable for underground $\mathrm{CO}_{2}$ storage. The Arabian Journal for Science and Engineering, DOI 10.1007/s13369-013-0862-0.

Wollenweber et al. 2009 - Wollenweber J., Alles S., Kronimus A., Busch Helge Stanjekd A., Krooss B.M., 2009 - Caprock and overburden processes in geological $\mathrm{CO}_{2}$ storage: An experimental study on sealing efficiency and mineral alterations. Energy Procedia 1, 1, pp. 3469-3476.

Zarębska et al. 2012 - Zarębska K., Baran P., Cygankiewicz J., Dudzińska A., 2012 - Sorption of carbon dioxide on Polish coals in low and elevated pressure. Fresenius Environmental Bulletin, 21(12b). pp, 4003-4008. 


\section{ZMIANY PETROGRAFICZNO-MINERALOGICZNE I TEKSTURALNE W SKALACH ZBIORNIKOWYCH I NADKLADU (ANTYKLINA ZAOSIA) W WYNIKU \\ DLUGOTERMINOWEGO EKSPERYMENTU ODDZIALYWANIA $\mathrm{CO}_{2}$-SKALA-SOLANKA}

\section{Słowa kluczowe}

CCS, badania petrograficzno-mineralogiczne, analizy teksturalne, antyklina Zaosia

\section{Streszczenie}

Artykuł przedstawia wyniki badań mineralogiczno-petrograficznych oraz teksturalnych na próbkach skalnych ze skał zbiornikowych i uszczelniających (piaskowce, iłowce, mułowce) z utworów dolnej jury z antykliny Zaosia (środkowa Polska), z otworów wiertniczych Zaosie 2 i Buków 2. Próbki poddano eksperymentowi oddziaływania $\mathrm{CO}_{2}$-solanka-skała celem określenia ich przydatności pod kątem geologicznej sekwestracji $\mathrm{CO}_{2}$. Eksperyment polegał na zamknięciu próbek skalnych na 20 miesięcy w zbudowanym reaktorze, gdzie były one poddane oddziaływaniu solanki i dwutlenku węgla w temperaturze pokojowej $\left(20-25^{\circ} \mathrm{C}\right)$, przy ciśnieniu otrzymanym z butli z $\mathrm{CO}_{2}$ (ok. $6 \mathrm{MPa}$ ). Analizy mineralogiczno petrograficzne obejmowały obserwacje w świetle przechodzącym (planimetria), SEM-EDS, XRD próbek skalnych. Dodatkowo dla skał uszczelniających wykonano XRD z frakcji ilastej. Badania te pozwoliły określić skład mineralny oraz morfologię ziaren jak również strukturę i teksturę skały. W przypadku analiz teksturalnych określona została powierzchnia właściwa BET oraz rozkład i wielkość porów. Miały na celu określenie zmian w matrycy skalnej i spoiwie badanych skał w wyniku eksperymentu oddziaływania pomiędzy solanką-skałą- $\mathrm{CO}_{2}$. Eksperyment nie wpłynął znacząco na badane parametry. W przypadku każdej z analizowanych skał obserwuje się nieznaczne zmiany w porowatości przed i po eksperymencie, co związane jest z rozpuszczaniem się matrycy skalnej i spoiwa oraz wytrącaniem niektórych faz mineralnych. Zmiany zaobserwowane w piaskowcach (skały zbiornikowe) są zmianami, które nie wpływają negatywnie na proces składowania $\mathrm{CO}_{2}$. W przypadku mułowców i iłowców (skał uszczelniających) wyniki badań pokazały, że eksperyment nieznacznie wpłynął na analizowane skały. Wskazywać to może na dobre właściwości uszczelniające tych skał. Niemniej jednak wyniki powinny zostać zweryfikowane i potwierdzone w uzupełnieniu o dalsze badania petrofizyczne (porowatość, przepuszczalność), analizy solanek przed i po eksperymencie, jak również modelowanie geochemiczne oddziaływania $\mathrm{CO}_{2}$ na skały w obecności solanki.

\section{PETROGRAPHIC-MINERALOGICAL AND TEXTURAL CHANGES IN RESERVOIR AND SEALING ROCKS (ZAOSIE ANTICLINE)}

AS A RESULT OF A LONG-TERM EXPERIMENT IN $\mathrm{CO}_{2}$-BRINE-ROCK INTERACTIONS

$$
\text { Key words }
$$

CCS, petrographic-mineralogical research, textural analysis, Zaosie anticline

\section{Abstract}

This article presents the petrographic-mineralogical and textural test results from rock samples from the reservoir and sealing rocks (sandstones, claystone, mudstone) of the Lower Jurassic formation of the Zaosie anticline (central Poland), from boreholes Zaosie 2 and Buków 2. Samples were subjected to an experiment involving $\mathrm{CO}_{2}$-brine-rock interactions in order to determine their suitability for the geological sequestration of $\mathrm{CO}_{2}$. The experiment consisted of closing the rock samples for 20 months in constructed autoclaves where they were subjected to the influences of brine and carbon dioxide at room temperature $\left(20-25^{\circ} \mathrm{C}\right)$ and under pressure (about $6 \mathrm{MPa}$ ). Mineralogical and petrographic analyses included observations under transmitted light (planimetric analysis), and SEM-EDS and XRD of rock samples were carried out. Additionally, XRD analysis 
of the clay fraction was conducted to examine the sealing characteristics of the rock. These studies allowed for the determination of the mineral composition and morphology of the grains as well as the structure and texture of the rocks. For the textural analysis, the BET specific surface area and pore size distribution were identified. The study aimed to determine the changes in the rock matrix and cement of the rocks caused by the brine-rock- $\mathrm{CO}_{2}$ interactions experiment. The experimentation did not significantly affect the analyzed parameters. For each of the examined rocks, little change in the porosity before and after the experiment was observed, which was associated with the dissolution of the rock matrix and cement as well as the precipitation of some mineral phases. The changes observed in the sandstones (reservoir rocks) are differences that do not affect the process of $\mathrm{CO}_{2}$ storage. In the case of mudstone and claystone (sealing rocks), the experiment had some slight effect on the analyzed rocks. This study nevertheless indicates good sealing properties of these rocks, though the results should be verified and proven by petrophysical (porosity, permeability) examination, the analysis of brines before and after the experiment, as well as geochemical modeling of the impact of $\mathrm{CO}_{2}$ on a rock in the presence of brine. 
